\title{
A case of solute diuresis erroneously diagnosed as lithium-induced polyuria
}

\section{H. Bendz}

Department of Psychiatry (Head: Prof. Robert Friedel), University of Michigan, Ann Arbor, Michigan, U.S.A.

Received September 15, 1984; accepted for publication September 29, 1984

Lithium (Li) treatment causes a substantial polyuria in some patients. Since this is a well known side effect of the treatment, its occurrence may distract the clinician from the possibility of other causes of polyuria in the patient. The following case report aims at illustrating the problem.

\section{Case report}

The patient is a Caucasian male born in 1943, with a diagnosis of bipolar affective disorder treated with $\mathrm{Li} \mathrm{CO}_{3}$ since March, 1982. The diagnostic work-up when first seen as an outpatient in this unit in May, 1982, included a physical examination and several blood and urine tests. They were all normal except for moderate obesity and increased serum cholesterol to $296 \mathrm{mg} / \mathrm{dl}$ (reference range 0-250). $\mathrm{He}$ was referred to an internist for the latter problem.

Between August, 1982, and October, 1983, his mood was kept reasonably stable by his Li treatment, sometimes supplemented by imipramine. His $\mathrm{Li}$ dose was kept between 1,800 and $3,000 \mathrm{mg}$ /day with $12 \mathrm{~h}$ plasma Li level (P-Li) averaging $0.71 \mathrm{mEq} / \mathrm{l}$ (range 0.49-1.09). In October, 1983, he reported being somewhat lethargic but not depressed. In January, 1984, he deteriorated (low energy, tense, irritable, down, withdrawing from social contacts; scaling skin; watery diarrhea) in a different way than when depressed. A physical examination was normal except for moderate obesity and dry oral mucosa. The following lab tests were all normal: S-K and $\mathrm{Na}, \mathrm{TSH}, \mathrm{T}_{3}$ RIA, $T_{4}$ resin, and $T_{4}$ RIA. Hemoglobin could not be analyzed because of lipemia.

Towards the end of January he became more clearly depressed and - since his physical work-up so far looked fairly normal was diagnosed as having a Li-modified depression. On January 19, he was put on imipramine. Two weeks later he felt better but was not back to normal, still having more of a physical than a psychic feeling of malaise. Imipramine and $\mathrm{Li}$ were continued unchanged.

Subjective polydipsia and polyuria were first reported in April, 1983, and again in July, 1983. He was always thirsty, urinating every $2 \mathrm{~h}$ during the day and once during the night. Nevertheless, he did not consider his polydipsia and polyuria a big problem. In October, 1983, he reported drinking 2-3 gallons (7.611.4 1) of fluid a day, having constant thirst and dry mouth. In January, 1984, 24-h urine volume $\left(V_{u}\right)$ was about 11.61 (average of 3 measurements). His polyuria was considered "most certainly Li-induced".

In the middle of February, he sought an ear-nose-throat specialist because of a change of taste (everything tasted salty). A diagnosis of oral mycosis and diabetes was made. On admission, February 17, 1984, his blood glucose level was elevated to $432 \mathrm{mg} / \mathrm{dl}$ but rapidly brought down to normal with insulin. $V_{\mathfrak{u}}$ was about $15 \mathrm{l}$. It quickly diminished with the normalization of blood glucose, averaging about 3.51 at discharge on February 
29. He has since been followed as an outpatient in the Departments of Internal Medicine and Psychiatry. His blood glucose remains stable. His mood stabilized on a euthymic level. Two months after discharge $\mathrm{V}_{\mathrm{u}}$ was 2.51 . His input, however, was 4.01 per $24 \mathrm{~h}$. There was no glucosuria. His medication at that time was: perphenazine $24 \mathrm{mg} /$ day; alprazolam $1.5 \mathrm{mg}$ at night; $\mathrm{Li} \mathrm{CO} 2400$ $\mathrm{mg}$ /day; Insulin Lente I $15 \mathrm{IU}$ in the morning.

\section{Discussion}

In our patient it is obvious from the course of events that solute diuresis (possibly present already several months before the diagnosis of diabetes mellitus was made) was the main reason for his massive polyuria, although, in addition, he probably also had, and still has, Li-induced (possibly reversible) nephrogenic polyuria. Precisely the massiveness of his polyuria, aside from other suggestive clinical evidence, should have alerted his psychiatrist to the possibility of some other cause than $\mathrm{Li}$. In general, $\mathrm{Li}$ is responsible for only a moderate polyuria. Few $\mathbf{L i}$ studies have reported individual values or group range for urinary output. For example Vestergaard (1) found among 218 patients ".. with satisfactory quantitative urine collection" a $V_{u}$ range of $0.7-9.2$ liters. We found among 162 patients, 124 of which have been published (2), a $V_{u}$ of 7.21 in one patient and $V_{u}>61$ in another 5 patients. Case reports give similar data although Rabin (3) in one patient found a urinary output of "9-16 $\mathrm{V} / \mathrm{d}$ ".

In general, therefore, with $\mathrm{Li}$ as the sole cause of polyuria, $V_{u}$ above 61 is found in only a few percent of $\mathrm{Li}$ patients, while values above 91 are rare.

\section{References}

1. Vestergaard $\mathbf{P}$, Amdisen A, Hansen $\mathbf{H} \mathbf{E}$ et al. Lithium treatment and kidney function. A survey of 237 patients in long-term treatment. Acta Psychiatr Scand 1979:60: 504-520.

2. Bendz H, Andersch S, Aurell M. Kidney function in an unselected lithium population. A cross-sectional study. Acta Psychiatr Scand 1983:68:325-334.

3. Rabin E Z, Garston R G, Weir R V et al. Persistent nephrogenic diabetes insidipus associated with long-term lithium carbonate treatment. Can Med Assoc J 1979: $121: 197-198$.

Address

Hans Bendz, M.D.

Psykiatriska Kliniken

St. Görans Sjukhus

Box 12500

S-112 81 Stockholm

Sweden 